2016

\title{
Interpretation: Article I, Section 5
}

Ronald Weich

Dean, University of Baltimore School of Law, rweich@ubalt.edu

Martin B. Gold

Partner, Capitol Counsel LLC, mgold@capitolcounsel.com

Follow this and additional works at: http://scholarworks.law.ubalt.edu/all_fac

Part of the Constitutional Law Commons, and the Legislation Commons

\section{Recommended Citation}

Martin B. Gold \& Ronald Weich, Interpretation: Article I, Section 5, Interactive Constitution (2016), http://constitutioncenter.org/ interactive-constitution/interpretations/article-i-section-5-by-martin-gold-and-ronald-weich.

This Article is brought to you for free and open access by the Faculty Scholarship at ScholarWorks@University of Baltimore School of Law. It has been accepted for inclusion in All Faculty Scholarship by an authorized administrator of ScholarWorks@University of Baltimore School of Law. For more information, please contact snolan@ubalt.edu. 

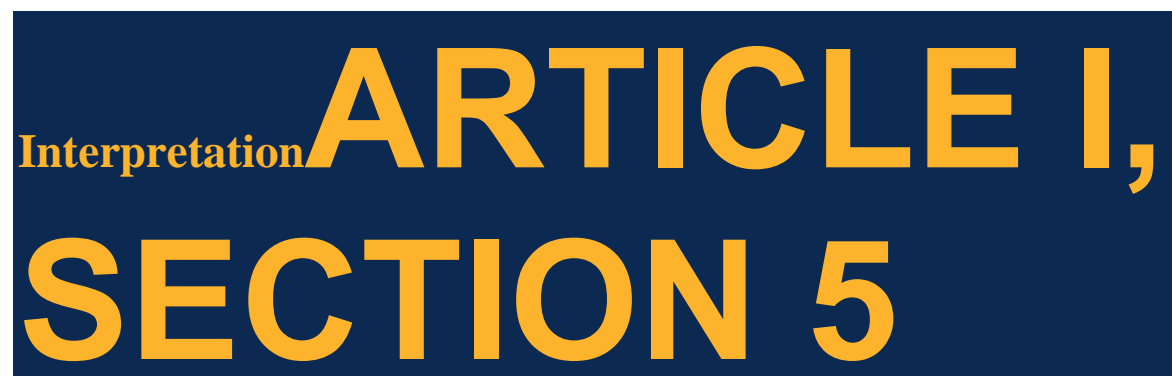

by: Martin B. Gold and Ronald Weich

Martin B. GoldPartner, Capitol Counsel LLC

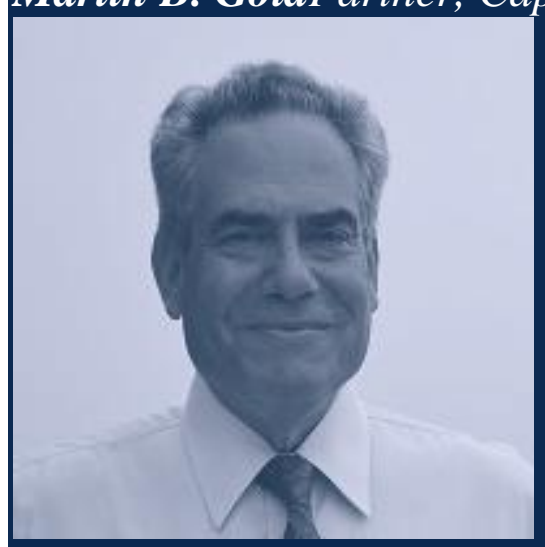

Ronald WeichDean and Professor of Law, University of Baltimore School of Law

In Article I of the Constitution, the Framers vest the legislative authority of the United States government in a bicameral Congress, and over the ten sections of the Article they systematically flesh out 
the structure, duties, and powers of that Congress. In the early sections of Article I they describe the membership of each House, giving life to the "Great Compromise" of the Constitutional Convention under which each state has equal representation in the Senate but populationbased representation in the House of Representatives. In Section 5, they grant Congress the power to govern itself.

Section 5 consists of four separate clauses, each of which addresses different practical aspects of legislative procedure.

The first Clause of Section 5 begins by bestowing on each House the power to "[j]udge" the elections of its own members. After the Civil War there were heated disputes about seating Senators from former Confederate states. But in the modern era, this provision comes into play when there is a challenge to the state-declared winner of an election to the Senate or House. Losing candidates dissatisfied with state recount procedures may petition the relevant chamber of Congress to decide the outcome. These high stakes determinations are immune from judicial review.

Legislative recounts can be bitterly partisan. For example, a House task force took months to review the 1984 election in Indiana's "Bloody Eighth" district, and GOP members walked out of the chamber in protest when Democrat Frank McCloskey was declared the winner over Republican Richard McIntyre by four votes out of 233,000 cast. In 1974, the Governor of New Hampshire certified that Republican Louis Wyman won a Senate seat by two votes. Democrat John Durkin sought redress in the Senate. Having conducted its own recount, the Senate Rules Committee reported a resolution that would have seated Durkin, but the resolution died in the face of implacable Republican opposition. Seven months into the new Congress, the 
Senate declared the seat vacant and sent the matter back to New Hampshire for a fresh election.

While the House and Senate may decide contested elections, they may not disqualify otherwise duly elected persons who meet Constitutional qualifications for membership. The House sought to do just that when the flamboyant Adam Clayton Powell won re-election to a New York seat. The Supreme Court held that a House of Congress may expel a member (by a two-thirds majority), but cannot exclude him for preelection conduct. Powell v. Mc Cormack(1969).

The same sentence in this Clause provides that "a majority of each [House] shall constitute a quorum to do business." Other than roll-call voting, most business in the chambers occurs with only a handful of members in attendance. But at any time any member may question the presence of a quorum, triggering a "quorum call." During a Senate quorum call, the clerk calls the names of every member to tally attendance. In most cases, the quorum call merely fills gaps between other Senate activities and is not intended to produce an actual quorum. When the Senate is ready to proceed to its business, the quorum call will typically be cut short by unanimous consent.

Neither chamber can conduct business without a quorum, but the Supreme Court long ago held that each House determines whether a quorum is present when a bill passes. Article I, Section 5 contemplates the compelled attendance of absent members, a device rarely utilized in the modern Congress.

The second Clause of Section 5 states that "Each House may determine the Rules of its Proceedings." This is an important provision because legislative rules often influence substantive outcomes. For example, the House Rules Committee determines which amendments may be offered to particular bills, thus shaping the 
debate on and ultimate content of legislation. Precedents interpreting Senate rules dictate preferential recognition of the Majority Leader over other Senators, a significant advantage for the Leader in setting the chamber's agenda.

Senate Rule 22 is a high-profile example of the power of legislative rulemaking. That rule establishes a three-fifths threshold (rather than a simple majority) to invoke "cloture" and thereby limit debate. In recent years, each party has accused the other of abusing the right of extended debate. Leaders of both parties threatened to change Rule 22 unilaterally to insulate certain questions from the super-majority requirement of cloture. A Republican threat to utilize this co-called "nuclear option" failed to materialize in 2005. Eight years later, Democrats who had opposed the nuclear option when they were in the minority successfully invoked it when they were in the majority to speed confirmation of nominees. Meanwhile litigation brought to challenge the constitutionality of Rule 22 failed because the Constitution explicitly reserves questions of Congressional selfgovernance to the Senate and House themselves. See, e.g., Common Cause v. Biden (D.C. Cir. 2014).

This second Clause also gives each legislative chamber the power to "punish its Members for disorderly behavior, and, with the concurrence of two thirds, expel a Member." In all of American history, only five House members and twenty Senators (most during the Civil War era) have been expelled from Congress, but many more have been punished with censure or reprimand for ethical misconduct. Most recently, James Traficant of Ohio was expelled from the House in 2002 following his conviction for bribery; five years earlier Senator Bob Packwood of Oregon resigned following the recommendation of the Ethics Committee that he be expelled for sexual harassment and related misconduct. It is important to note that either chamber can exercise the power of expulsion without waiting for a criminal 
conviction. Thus, even though the House acted on Traficant after his conviction, no criminal charges had been brought against Packwood.

The third Clause of Section 5 states that each House "shall keep a Journal of its Proceedings" which must be published "from time to time." In an era of Internet live streaming, the daily publication of the Congressional Record may seem quaint. But the unequivocal constitutional command of transparency and public access in Article I, Section 5 is actually a cornerstone of American democracy. The Clause recognizes that secrecy might sometimes be needed, but moments when the C-SPAN cameras are turned off, for example when the Senate deliberates as a jury about articles of impeachment, are exceedingly rare. The Journal of each chamber is the official record of its proceedings, supplemented today by committee reports and many other forms of public access.

This Clause also enshrines the value of public accountability: a mere one-fifth of the members present on the floor of either chamber may demand a recorded roll call vote. Roll call votes in the House are tallied electronically, but Senate clerks call the names of each of the 100 members and record the outcome by hand. A Senate roll call vote is one of the most vivid demonstrations of representative democracy.

The final Clause of Section 5 says that "[n]either House, during the Session of Congress, shall, without the Consent of the other, adjourn for more than three days, nor to any other Place than that in which the two Houses shall be sitting." This archaic-sounding provision is a necessary element of bicameralism; the Founders were worried that the will of one House might be thwarted by the other's mischievous absence.

House and Senate leaders typically work out a joint or concurrent resolution providing for adjournment, but some partisan 
gamesmanship may prevent it. For example, in 2007, Senate Majority Leader Harry Reid announced that the Senate would hold pro-forma sessions every three days so that President George W. Bush could not make recess appointments. In 2012, the Republican-led House prevented the Senate from adjourning, so that President Barack Obama could not make such appointments. The Supreme Court recently reminded the president that it is the prerogative of Congress to determine when it is in recess. NLRB v. Noel Canning (2014). Section 5 of Article 1 does not contain all of the "How To" instructions for legislative proceedings. The impeachment process, for example, is set forth in Section 3. The process for overriding presidential vetoes appears in Section 7. Several constitutional amendments have revised legislative procedures, such as the Seventeenth Amendment providing for the direct election of Senators. But Article 1, Section 5 of the Constitution is important because it establishes some of the most fundamental building blocks of our timehonored system of government. 